\title{
ORIENTASI PEMERINTAH DAERAH DALAM PEMBERDAYAAN MASYARAKAT PESISIR (NELAYAN) DI DUSUN MAMUA DESA HILLA KECAMATAN LEIHITU
}

\author{
Farah Dessy Tuasamu \\ Dosen Universitas Darussalam Ambon
}

\begin{abstract}
Abstrak
Pemberdayaan pada hakekatnya adalah upaya pemberian daya atau peningkatan keberdayaan. Pemberdayaan masyarakat dapat diartikan sebagai upaya untuk memandirikan masyarakat agar mampu berpartisipasi aktif dalam segala aspek pembangunan. Dusun Mamua Desa Hila merupakan Kecamatan Leihitu yang sebagian besar penduduknya bermukim atau bertempat tinggal diwilayah pesisir. Secara umum masyarakat pesisir hidupnya tergantung dari pemanfaatan dan pengelolaan sumber daya perikanan, seperti : nelayan, pembudidaya ikan, pengolah ikan, kepiting, gonggong dan pedagang ikan. sebagian besar dari mereka termasuk nelayan tradisional dengan tingkat pendidikan yang relatif rendah. umumnya penghasilan mereka masih tergantung pada kondisi alam, maka sulit bagi mereka untuk merubah kehidupannya menjadi lebih baik. Sebagai nelayan tradisional bukan saja berhadapan dengan ketidakpastian pendapatan, tetapi mereka juga dihadapkan manajemen pengelolaan keuangan dan pemasaran hasil produksinya. Jenis penelitian ini menggunakan jenis penelitian dikskriptif kualitatif. Tempat penelitian adalah pada Dusun Mamua,Desa Hila Kecamatan Leihitu Kabupaten Maluku Tengah.

Informan dalam penelitian ini berjumlah 10 orang yang terdiri dari kepala desa, kepala dusun, sekretaris dusun dan masyarakat. Teknik pengumpulan data dilakukan dengan Observasi ,Wawancara dan Dokumentasi. Data-data yang di kumpulkan kemudian diinterprestasikan secara kualitatif .

Hasil penelitian menunjukkan bahwa dalam perencanaan orientasi sasaran pemberdayaan masyarakat nelayan sudah sering dilakukan hingga semua kebutuhan yang dibutuhkan oleh masyarakat dalam hal ini kelompok nelayan sudah dituangkan kedalam proposal yang diajukan kepada Dinas Perikanan. Tingkat kebutuhan masyarakat nelayan. Hingga saat ini masyarakat nelayan belum mendapatkan bantuan apapun dari dinas perikanan yang mana bantuan yang diharapakan dapat meningkatkan tarap hidup mereka. Evaluasi sasaran pemberdayaan masyarakat nelayan. Melihat semua hal tersebut masyarakat sangat kecewa dikarenakan kebutuhan mereka tidak terpenuhi sesuai dengan keinginan mereka
\end{abstract}

Kata Kunci : Pemberdayaan, masyarakat, nelayan. 


\section{Pendahuluan}

Pemberdayaan pada hakekatnya adalah upaya pemberian daya atau peningkatan keberdayaan. Pemberdayaan masyarakat dapat diartikan sebagai upaya untuk memandirikan masyarakat agar mampu berpartisipasi aktif dalam segala aspek pembangunan. Kemandirian bukan berarti mampu hidup sendiri tetapi mandiri dalam pengambilan keputusan, yaitu memiliki kemampuan untuk memilih dan keberanian menolak segala bentuk bantuan dan atau kerjasama yang tidak menguntungkan.

Berbagai upaya telah dilakukan oleh pemerintah untuk berusaha meningkatkan tingkat kesejahteraan masyarakat nelayan, baik melalui pemberian bantuan peralatan tangkap, kemudahan akses permodalan, maupun melalui program pemberdayaan masyarakat pesisir. Dimana semua program tersebut bertujuan untuk meningkatkan kesejehteraan masyarakat pesisir, termasuk nelayan.

Kementerian Kelautan dan Perikanan (KKP 2010) dalam (Iwan Nugroho 2012 : 284 ) menyusun visi "indonesia menjadi penghasil produk kelautan dan perikanan terbesar 2015" dan misi "mensejahterakan masyarakat kelautan dan perikanan". Visi dan Misi tersebut diharapkan dapat menjadi tuntunan bagi pembangunan sektor kelautan dan perikanan yang berpihak kepada rakyat.

Seperti yang dikatakan oleh Tjokroamidjojo dalam (Haryono Sudriamunawar. 2006) bahwa peran pemerintah dalam pembangunan sangat dominan, namun harus diakui pula bahwa pemerintah seringkali harus bertindak sebagai unsur pembaharu, pembimbing, pengarah melalui perencanaan pembangunan. Kemampuan masyarakat untuk mendapatkan kebutuhan-kebutuhan yang sebenarnya juga dirasakan mengalami hambatan.

Dusun Mamua Desa Hila merupakan Kecamatan Leihitu yang sebagian besar penduduknya bermukim atau bertempat tinggal diwilayah pesisir. Secara umum masyarakat pesisir hidupnya tergantung dari pemanfaatan dan pengelolaan sumber daya perikanan, seperti : nelayan, pembudidaya ikan, pengolah ikan, kepiting, gonggong dan pedagang ikan. sebagian besar dari mereka termasuk nelayan tradisional dengan tingkat pendidikan yang relatif rendah. umumnya 
penghasilan mereka masih tergantung pada kondisi alam, maka sulit bagi mereka untuk merubah kehidupannya menjadi lebih baik. Sebagai nelayan tradisional bukan saja berhadapan dengan ketidakpastian pendapatan, tetapi mereka juga dihadapkan manajemen pengelolaan keuangan dan pemasaran hasil produksinya.

Bantuan yang diberikan pemerintah khususnya Dinas Kelautan dan Perikanan kepada masyarakat nelayan dusun Mamua, pada kenyataannya tidak membantu atau mengubah kehidupan masyarakat tersebut. Masyarakat nelayan Dusun Mamua menginginkan adanya hubungan langsung antara pemerintah dan masyarakat nelayan, sehingga masyarakat dapat menyatakan langsung bantuan seperti apa yang dibutuhkan oleh seluruh masyarakat nelayan Dusun Mamua tersebut serta menghindari terjadinya proses pemberdayaan yang tidak tepat sasaran atau tidak tepat fungsi.

\section{Rumusan Masalah}

Dengan mengacu pada latar belakang yang di kemukakan di atas, maka yang menjadi permasalahan dalam penelitian ini adalah: Bagaimana Pemberdayaan Masyarakat Pesisir (Nelayan) Di Dusun Mamua, Desa Hila Kecamatan Leihitu Kabupaten Maluku Tengah.

\section{Tujuan Penulisan}

Dalam setiap penelitian pada dasarnya memiliki beberapa tujuan yang hendak dicapai, adapun tujuan dari penelitian ini adalah: Untuk Mengetahui Proses Pemberdayaan Masyarakat Nelayan Di Dusun Mamua Desa Hila Kecamatan Leihitu Kabupaten Maluku Tengah.

\section{Kegunaan Penelitian}

1. Menunjukan secara ilmiah proses dan mekanisme pemberdayaan masyarakat pesisir khususnya masyarakat nelayan di Dusun Mamua Desa Hila, Kecamatan Lehitu. 
2. Memberikan bahan rujukan kepada masyarakat yang berminat dalam memahami proses pemberdayaan masyarakat di dusun mamua.

\section{B. Teori Dan Konsep}

\section{Pemberdayaan Masyarakat}

Pemberdayaan adalah upaya untuk menciptakan/ meningkatkan kapasitas masyarakat baik individu maupun berkelompok, dalam memecahkan berbagai persoalan terkait upaya peningkatan kualitas hidup, kemandirian, dan kesejahteraannya. Secara konseptual, pemberdayaan masyarakat adalah upaya untuk meningkatkan harkat dan martabat lapisan masyarakat yang dalam kondisi sekarang tidak mampu untuk melepaskan diri dari perangkap kemiskinan dan keterbelakangan. Dengan kata lain memberdayakan adalah memampukan dan memandirikan masyarakat.

Menurut Damanhuri, D. dan L. Arianto $(1995,9)$ bahwa pemberdayaan masyarakat merupakan upaya untuk memandirikan masyarakat lewat perwujudan potensi kemampuan yang mereka miliki. Adapun pemberdayaan masyarakat senantiasa menyangkut dua kelompok yang saling terkait, yaitu masyarakat sebagai pihak yang diberdayakan dan pihak yang menaruh kepedulian sebagai pihak yang memberdayakan.

Sedangkan menurut Dipokusumo, (1999, 6), manusia adalah subjek dari dirinya sendiri. Proses pemberdayaan yang menekankan pada proses memberikan kemampuan kepada masyarakat agar menjadi berdaya, mendorong atau memotivasi individu agar mempunyai kemampuan atau keberdayaan untuk menentukan pilihan hidupnya. Lebih lanjut dikatakan bahwa pemberdayaan harus ditujukan pada kelompok atau lapisan yang tertinggal.

\section{Pemerintah Daerah}

Perubahan ke 4 (empat) UUD 1945 menyatakan jelas mengenai bentuk dan susunan pemerintahan daerah dalam kerangka Negara Republik Indonesia. Pasal 18 ayat (1) berbunyi :“ Negara Kesatuan Repulik Indonesia dibagi atas daerah-daerah propinsi dan daerah propinsi itu dibagi atas kabupaten dan kota, 
yang tiap-tiap propisi, kabupaten dan kota itu mempunyai pemerintahan daerah yang diatur Undang-Undang”. Sedang Pasal 18 ayat (5) UUD 1945 menyebutkan bahwa:"pemerintah daerah merupakan daerah otonom yang dapat menjalankan urusan pemerintahan dengan seluas-luasnya serta mendapat hak untuk mengatur kewenangan pemerintahan kecuali urusan pemerintahan yang oleh undang-undang ditentukan sebagai urusan pemerintahan pusat".

Definisi Pemerintah Daerah di dalam UU No. 32 Tahun 2004 tentang pemerintahan daerah pasal 1 ayat 2 adalah sebagai berikut Pemerintahan Daerah adalah penyelenggaraan urusan pemerintahan oleh pemerintahan daerah dan DPRD menurut asas otonomi dan tugas pembantuan dengan prinsip otonomi yang seluas-luasnya dalam sistem dan prinsip Negara Kesatuan Republik Indonesia sebagaimana dimaksud dalam Undang-Undang Dasar Negara Republik Indonesia Tahun 1945". Melihat definisi pemerintahan daerah seperti yang telah dikemukakan diatas, maka yang dimaksud pemerintahan daerah disini adalah penyelenggaraan daerah otonom oleh Pemerintah Daerah dan DPRD menurut asas desentralisasi dimana unsur penyelenggara pemerintah daerah adalah Gubernur, Bupati atau Walikota dan perangkat daerah.

\section{Pemberdayaan Masyarakat Pesisir}

Pemberdayaan masyarakat adalah upaya untuk menciptakan atau meningkatkan kapasitas masyarakat, baik secara individu maupun berkelompok, dalam memecahkan berbagai persoalan terkait upaya peningkatan kualitas hidup, kemandirian dan kesejahteraannya. Pemberdayaan masyarakat memerlukan keterlibatan yang besar dari perangkat pemerintah daerah serta berbagai pihak untuk memberikan kesempatan dan menjamin keberlanjutan berbagai hasil yang dicapai.

Masyarakat pesisir adalah masyarakat yang terdiri atas nelayan, pembudidaya ikan, pengolah dan pedagang hasil laut, serta masyarakat lainnya yang kehidupan sosial ekonominya tergantung pada sumberdaya kelautan (Saad 2003) Karakteristik masyarakat pesisir berbeda dengan karakteristik sumberdaya alam yang dihadapi. Masyarakat pesisir menghadapi sumberdaya alam yang dapat 
dikontrol, mobilitas usaha relatif rendah dan unsur resiko tidak terlalu besar, sedangkan nelayan yang bekerja menangkap ikan di laut menghadapi sumberdaya alam yang terbuka dan sulit di kontrol.

Menurut Soeharto (2006), dalam memperdayakan masyarakat nelayan harus dengan jalan pemberian bantuan kebutuhan hidup seketika, bukanlah upaya memecahkan masalah, namun hanya merupakan bantuan sementara. Pemberdayaan memerlukan sentuhan teknologi karena pada hakikatnya pemberdayaan masyarakat adalah perubahan sosial untuk memanfaatkan sumberdaya alam dalam rangka meningkatkan kesejahteraan sesuai dengan suasana sosial budaya dan sosial ekonomi yang ada.

\section{Metode Penelitian}

Jenis penelitian ini menggunakan jenis penelitian dikskriptif kualitatif. Tempat penelitian adalah pada Dusun Mamua,Desa Hila Kecamatan Leihitu Kabupaten Maluku Tengah.

Informan dalam penelitian ini berjumlah 10 orang yang terdiri dari kepala desa, kepala dusun, sekretaris dusun dan masyarakat.

Teknik pengumpulan data dilakukan dengan Observasi ,Wawancara dan Dokumentasi. Data-data yang di kumpulkan kemudian diinterprestasikan secara kualitatif .

\section{Hasil dan Pembahasan}

\section{Perencanaan Orientasi Sasaran Pemerdayaan Masyarakat Nelayan}

Perencanaan sebagai alat mencapai tujuan. Perencanaan dilakukan untuk mencapai tujuan tertentu (tentunya sesuatu yang lebih baik) maka berorientasi pada tindakan. Tujuan yang diinginkan dapat menyelesaikan persoalan jangka pendek, jangka menengah, maupun jangka panjang.

Perencanaan berorientasi kepada perbaikan yang secara sadar diinginkan dan berupaya agar terjadi perbaikan yang sistematis dan diinginkan. Perencanaan menyangkut pula penjadwalan tindakan-tindakan secara logis, bertahap, berkesinambungan, sesuai dengan rangkaian sasaran atau target untuk mencapai tujuan. Perencanaan tersebut guna menjawab semua permasalahan yang menjadi 
keluhan semua masyarakat khususnya masyarakat nelayan yang ada di dusun mamua negeri hila kecamatan leihitu kaupaten Maluku tengah.

Sesuai hasil wawancara dengan informan :

bahwa mereka membentuk kelompok-kelompok nelayan yang terdiri dari badan pengurus, ketua, anggota dan yang lainnya. organisasi yang telah di bentuk kemudian terpilih ketua untuk memimpin kelompok kami agar bagaimana kelompok yang telah kami bangun ini bisa berjalan sesuai kesepakatan yang telah kami buat bersama yaitu melengkapi peralatan yang dibutuhkan seperti jaring, perahu dan tempat penampungan ikan dan menyusun jadwal kegiatan kelompok setelah itu persiapan untuk bagaimana kegiatan akan dijalankan. Selanjutnya kelompok-kelompok nelayan mengadakan rapat guna membahas bagaimana cara mendapatkan bantuan dari pemerintah. Dari hasil rapat tersebut masingmasing kelompok merencanakan secara mandiri apa yang menjadi kebutuhan yang selama ini menjadi kendala bagi mereka. (hasil wawancara 2015).

Kemudian jawaban yang sama pula dari salah seorang masyarakat Dusun

Mamua beliau mengatakan bahwa:

Pernah ada rapat dengan Kepala UPT Leihitu, pertemuannya tentang kerjasama dari para kelompok-kelompok nelayan dan masyarakat dengan tujuan agar meningkatkan usaha dan membahas tentang bagaimana usaha ini bisa berkembang dan berjalan dengan lancar. Waktu itu mereka janji akan menurunkan bantuan kepada nelayan didusun mamua ini tapi sampai sekarang janji itu tidak ditepati malahan sekarang mereka seakan dan tidak memperdulikan apa yang menjdi kebutuhan kami.(Hasil Wawancara 2015).

Dari hasil penjelasan diatas bahwa terkait dengan Perencanaan Orientasi Sasaran Pemberdayaan Masyarakat Pesisir (nelayan). Sudah dilakukan dengan cara mengadakan musyawarah guna mengetahui keinginan dari para nelayan terkait apa-apa saja yang sangat dibutuhkan. Hal ini dilakukan dengan melibatkan semua kalangan, yaitu kepala dusun, sekertaris dusun, tokoh-tokoh masyarakat, dan juga kelompok-kelompok nelayan.

\section{Tingkat kebutuhan masyarakat nelayan}

Dari ilustrasi sederhana dapat dilihat bagaimana kebutuhan hidup manusia itu menyatu dengan nilai - nilai masyarakat pendukung kebudayaan. Selain pengaruh lingkungan hidup baik yang berwujud lingkungan alam, sosial dan 
lingkungan buatan, menyatu kuat dalam keputusan-keputusan yang diambil manusia dalam memenuhi kebutuhan hidupnya itu. Dari perspektif yang lebih luas, dalam kebutuhan hidupnya manusia itu dapat pula dilihat dari dimensi yang menyangkut kebutuhan manusia sebagai individual, sosial dan moral, dan ketiga dimensi itu selalu kait mengait dalam pemenuhan kebutuhan hidupnya itu.

Untuk itu nelayan tradisional di Dusun Mamua berusaha untuk menyeimbangkan pendapatan yang dihasilkan dengan pengeluaran yang dibutuhkan untuk keperluan mereka sehari-hari. Jika mereka tidak pandai dalam mengatur keuangan, maka kebutuhan ekonomi nelayan tidak akan terpenuhi dan akan tetap berada pada garis kemiskinan.

Hal tersebutlah yang membuat nelayan tidak pernah berputus asa dalam menjalani profesi mereka sebagai nelayan tradisional, karena walaupun dikatakan miskin tetapi mereka masih tetap mampu untuk bertahan hidup.

Menurut salah seorang nelayan (kelompok 1) bapak Syukur beliau mengatakan bahwa:

Yang menjadi kebutuhan dari nelayan adalah berupa, (perahu, mesin, tasi dank kail) namun sampai sekarang pemerintah tidak menghiraukan proposal yang kami ajukan kepada mereka. Jujur kami sebagai kelompok nelayan sangat kecewa karna setiap proposal yang kami ajukan tidak pernah ada respon balik kepada kami, kami tidak pernah menuntut banyak dari pemerintah cukup kepedulian mereka kepada kami selaku kelompok nelayan yang kami harapkan. Tapi, sampai sekarang keinginan itu tidak terwujud bahkan sampai sekarang belum pernah ada bantuan.

(Hasil wawancara, 2015)

Selanjutnya ditambahkan oleh bapak La Utu (nelayan kelompok 2) beliau mengatakan bahwa:

Terakhir kali bantuan itu diberikan yaitu pada tahun 2009 dan bantuan tersebutpun hanya saat PILKADA saja khusus bantuan dari dinas perikanan belum ada. Sampai sekarang kami selaku kelompok nelayan sangat membutuhkan bantuan dari Pemerintah khususnya Dinas Perikanan, kemudian kami sepakat untuk mengadakan rapat agar bagaimana kelompok-kelompok nelayan yang berada d Dusun Mamua ini bisa terus berjalan dan berkembang. Terkait dengan bantuan yang diberikan kepada masyarakat (nelayan) saat pilkada tersebut belum tepat sasaran karena bantuan yang diberikan tersebut tidak terpenuhi sesuai dengan apa yang dibutuhkan oleh masyarakat (nelayan). Kami selaku 
kelompok nelayan menginginkan adanya hubungan langsung dengan pemerintah agar kami bisa menyatakan langsung bantuan seperti apa yang kami kami butuhkan, Tpi yang kami inginkan tidak sama dengan kenyataan karna proposal yang kami ajukan saja tidak di perdulikan. Kami berharap ada jalan bagaimana pemerintah bisa melihat kendala dari kebutuhan kami nantinya.

(Hasil wawancara, 2015)

Kebutuhan masyarakat (nelayan) saat ini sangat tidak sesuai dengan apa yang diberikan oleh pemerintah, dan pemberian tersebut juga terkecuali adanya pilkada baru masyarakat bisa mendapatkan bantuan, sampai sekarangpun masyarakat tidak pernah mendapatkan apa yang sesuai dengan keinginan mereka dari dinas perikanan dikarenakan semua proposal yang diajukan mungkin saja tidak dihiraukan makanya sampai sekarangpun bantuan tidak pernah ada buat masyarakat (nelayan) yang ada didusun mamua.

\section{Evaluasi Orientasi Sasaran Pemberdayaan Masyarakat Nelayan}

Evaluasi adalah suatu proses untuk menyediakan informasi tentang sejauh mana suatu kegiatan tertentu telah dicapai, bagaimana perbedaan pencapaian itu dengan suatu standar tertentu untuk mengetahui apakah ada selisih di antara keduanya, serta bagaimana manfaat yang telah dikerjakan itu bila dibandingkan dengan harapan-harapan yang ingin diperoleh.

Dapat dilihat bahwa tidak adanya bantuan yang diberikan oleh pemerintah dalam hal ini dinas perikanan untuk kebutuhan masyarakat. Kelompok nelayan selalu memgadakan pertemuan dengan pemerintah Dusun guna memberikan masukan dan keluhan.

Menurut salah seorang tokoh masyarakt bapak La Pilipina beliau mengatakan bahwa:

Kami selaku kelompok-kelompok nelayan dulunya selalu mengadakan kegiatan secara terus menerus untuk melihat perkembangaun usaha kami dalam meningkatkan hasil usaha yang sedang berjalan. Tapi sekarang kami sudah jarang mengadakan pertemuan, banyak dari teman-teman kelompok yang merasa kecewa karna setiap proposal yang kami ajukan tidak pernah diperhatikan oleh pemerintah. Kami bisa menjalankan usaha ini tapi tanpa ada bantuan juga kami tidak bisa melakukan banyak hal karna keterbatasan modal.(Hasil wawancara, 2015) 
Selanjutmya ditambahkan oleh bapak Udin salah seorang tokoh masyarakat beliau mengatakan bahwa:

Dari tahun 2008 hasil dari perencanaan orientasi tidak maksimal karena jenis bantuan yang diturunkan dari pemerintah melalui program pilkada tidak memadai/tepat karena bantuan yang diberikan tidak sesuai dengan kebutuhan masyarakat (nelayan). Masyarakat nelayan khususnya tidak merasa puas dengan perencanaan orientasi tersebut karena tidak adanya perhatian dari pemerintah selama ini, yang kami inginkan adanya hubungan langsung antara pemerintah dan masyarakat nelayan, sehingga apa yang menjadi keluhan kami bisa lansung didengar oleh mereka, karna setiap permohonan yang kami ajukan tidak pernah diperdulikan.

(Hasil wawancara, 2015)

Dari semua penyataan yang dijelaskan diatas dapat dilihat bahwa tidak adanya bantuan yang diberikan kepada masyarakat dalam hal ini nelayan yang membutuhkan bantuan berupa perahu, dan mesin yang menjadi kebutuhan utama dari masyarakat nelayan yang ada di Dusun Mamua Negeri Hila Kecamatan Leihitu Kabupaten Maluku Tengah dikarenakan semua proposal-proposal yang diajukan kepada dinas perikanan guna memenuhi semua kebutuhan nelayan tidak dihiarukan.

Pemerintah dusun selalu mengadakan pertemuan dengan semua kelompok nelayan yang ada di Dusun Mamua Negeri Hila guna melihat semua yang menjadi keluhan bagi kelompok-kelompok nelayan dan ternyata banyak keluhan dari kelompok-kelompok nelayan yang hingga saat ini belum terealisasikan dengan baik oleh pemerintah (Dinas Perikanan). Yang mana setiap proposal yang dimasukan seakan-akan tidak diindahkan oleh pemerintah.

\section{E. Kesimpulan}

Adapun kesimpulan dari semua penjelasan yang dijelaskan pada bab 4 diatas antara lain sebagai berikut:

1. Perencanaan orientasi sasaran pemberdayaan masyarakat nelayan sudah sering dilakukan hingga semua kebutuhan yang dibutuhkan oleh masyarakat dalam hal ini kelompok nelayan sudah dituangkan kedalam proposal yang diajukan kepada Dinas Perikanan. 
2. Tingkat kebutuhan masyarakat nelayan. Hingga saat ini masyarakat nelayan belum mendapatkan bantuan apapun dari dinas perikanan yang mana bantuan yang diharapakan dapat meningkatkan tarap hidup mereka.

3. Evaluasi sasaran pemberdayaan masyarakat nelayan. Melihat semua hal tersebut masyarakat sangat kecewa dikarenakan kebutuhan mereka tidak terpenuhi sesuai dengan keinginan mereka

\section{F. Saran}

Adapun saran dari peneliti melihat dari semua persoalan yang terjadi pada masyarakat nelayan sesuai dengan penjelasan-penjelasan diatas.

1. Pemerintah harus lebih memperhatikan masyarakat yang membutuhkan bantuan dari tangan pemerintah.

2. Pemerintah harus lebih jelih melihat masalah ini khususnya masyarakat nelayan agar bagaimana bantuan yang menjadi harapan masyarakat dapat terpenuhi. Untuk itu kebijakan dan program pemberdayaan untuk masyarakat nelayan juga sebaiknya dilakukan.

3. Pemerintah harus upayakan bisa menyediakan bantuan khusus untuk menyalurkan kepada masyarakat nelayan. Bantuan yang diberikan bukan demi kepentingan pribadi saja tetapi bantuan yang diberikan harus dengan iklas bukan untuk mengharapkan imbalan.

\section{DAFTAR PUSTAKA}

Bambang dan Mansyur Effendi. 1998. Paradigma, Strategi dan Langkah Pemberdayaan Ekonomi pedesaan. Surabaya : LSK

Damunhuri, D. dan L. Arianto, !995, Dimensi Sosial Ekonomi Dalam Kerangka Pembangunan Masyarakat Pesisir, Makalah Pertemuan Ilmiah Badan Pembinaan Hukum Nasional, Jakarta

Dr. Irawan Soehartono, 1995. Metode Penelitian Sosial, Bandung : PT Remaja Rosdakarya

Iwan Nugroho, 2012. Kementrian Kelautan dan Perikanan, Jakarta 
Kencana Syafiie Inu, 2011, Pengantar Ilmu Pemerintahan, Bandung : PT RefikaA ditama.

Mikkelsen, I.Nyoman Sumaryadi, 2005, Perencanaan Pembangunan Daerah dan Pemberdayaan Masyarakat, Jakarta: citra utama.

Menteri Lokakarya Pemberdayaan Masyarakat Pesisir. Jakarta. Tanggal 26 Februari. 2003.

Natuna Daeng Ayub, dkk, 2009, Pendidikan dan Pembangunan Berbasis Maritim, Tanjung pinang: UMRAH Press.

Prijono dan Pranaka, 1996. Proses Pemberdayaan dan motivasi masyarakat, Jakarta

Soeharto, 2006.Model-Model Pemberdayaan Masyarakat, Alfa beta, Bandung

Stainback, susan, 2005. Memahami Penelitian Kualitatif, Bandung: alfa beta.

Subade dan Abdullah, 1993. Industri Perikanan dan Opportunity cost. Bandung

Sumodiningrat, 1999. Pemberdayaan Masyarakat dan Memandirikan Masyarakat lewat perwujudan potensi. Jakarta: Bumi aksara

Tjokroamidjojo, Haryono Sudriamunawar, 2006. Peran Pemerintah dan Perencanaan Pembangunan, Jakarta

\section{Sumber-sumber lain}

Peraturan Daerah Kota Tanjung pinang nomor 6 tahun 2005 Tentang Retribusi Usaha Perikanan.

Pasal 18 ayat (5) UUD 1945 tentang Pemerintah Daerah

UU No. 32 Tahun 2004 tentang Pemerintah Daerah 